\title{
Decoding the Parallelism of Three Descents into Dante's Hell
}

\author{
Lloyd H. Howard
}

When Dante declares in Inf. 2.32: "Io non Enëa, io non Paulo sono," he is overtly establishing a link between his descent and their journeys. The other inevitable link between Dante's descent and that of Christ and Virgil is not stated in the text. It is the thesis of this study that there exists a linguistic code, a subtle declaration so far unobserved, that links openly together the descents of Christ, Virgil and Dante, and affirms the commonality of their purpose.

The code consists of the repetition of the noun "color" and the formula "vo" che sappi."2 In two cases only in the Commedia, "color" is chosen with the lexical connotation of pallor: Inf. 4.16 ("E io, che del color mi fui accorto") and Inf. 9.1 ("Quel color che vilta di fuor mi pinse"). ${ }^{3}$ In three instances in the Commedia, all in the first half of the Inferno, Virgil prefaces his explanations to Dante with the words "vo' che sappi." They occur in Inf. 4.33 ("Or vo' che sappi, innanzi che più andi"), Inf. 4.62 ("E vo' che sappi che, dinanzi ad essi") and Inf. 12.34 ("Or vo' che sappi che l'altra fiata"). The first component of this linguistic code, "color," guides us as far as Inferno 9 and the second one, "vo" che sappi," leads us ultimately to Inferno 12 . Inferno 9 and Inferno 12 are linked because in them there occur the two key instances where Virgil refers to his prior descent (and both times he repeats "l'altra fiata" to allude to when it took place). The linguistic formula "vo' che sappi" is a signal which leads the reader from Inferno 4, with its reference to the descensus Christi, to Inferno 12 where Christ's descent is once again recalled by Virgil along with his own descent to the 9th circle. The reference to Virgil's "color" and to the descensus Christi in Inferno 4, reappears in Inferno 9 where for the first time there is mention of Virgil's earlier descent. ${ }^{4}$ In all cases these words are employed when there is discussion of either the descensus Christi or Virgil's descent to Giudecca.

The first "vo' che sappi" occurs early in Inferno 4, as guide and pilgrim approach Limbo. Dante notices Virgil's pallor:

E io, che del color ${ }^{5}$ mi fui accorto, dissi: "Come verrò, se tu paventi che suoli al mio dubbiare esser conforto?"

(Inf. 4.16-18) 
Virgil's "color" gives rise to Dante's question regarding his guide's qualifications. Virgil responds with direct reference to his "color":

Ed elli a me: "L'angoscia de le genti che son qua giù, nel viso mi dipigne quella pietà che tu per tema senti."

Virgil assumes that Dante would have been curious about these "genti" who stirred that anguish in him which Dante had taken for fear. Thus when Dante does not ask who the "genti" are, Virgil mildly takes him to task and prompts the information himself:

Lo buon maestro a me: "Tu non dimandi che spiriti son questi che tu vedi? Or vo' che sappi, innanzi che più andi,

ch'ei non peccaro; e s'elli hanno mercedi, non basta, perché non ebber battesmo, ch'è porta de la fede che tu credi;

e s'e' furon dinanzi al cristianesmo, non adorar debitamente a Dio: e di questi cotai son io medesmo.

Per tai difetti, non per altro rio, semo perduti, e sol di tanto offesi che sanza speme vivemo in disio."

Virgil prefaces his description of the "genti," who had been the cause of his "color," with the words "vo' che sappi." Virgil "wants" Dante "to know," right now before going further, why these "genti" should be pitied: they did not sin other than by not having been baptized and yet they remain in Hell. ${ }^{6}$ The "or,"7 followed by the formula (verb of volition "vo" + "che" + the subjunctive "sappi"), followed by "before going further," compels Dante and the reader to pause and consider the magnitude of what is being said and the poignancy of Virgil being one of these souls ("e di questi cotai son io medesmo" 4.39). The context of the first occurrence of the formula serves to define the human dimension of Virgil's figure: the lofty poet is vulnerable, and it is precisely this vulnerability which humanizes him. In Limbo, the place of "sospiri" (4.26) and "duol" (4.28), Virgil's pallor causes Dante to fear that Virgil is ill-equipped to lead him, something Dante conveys clearly to his guide in lines 17 and 18.

The second occurrence of the formula "vo' che sappi" comes soon after the first, also in Inferno 4. Dante, reacting to what Virgil "had wanted" him "to know," queries his guide:

"Dimmi, maestro mio, dimmi, segnore," 
comincia' io per volere esser certo

di quella fede che vince ogne errore:

"uscicci mai alcuno, o per suo merto

o per altrui, che poi fosse beato?"

(Inf. 4.46-50)

Dante wants to ascertain that what he has learned by faith is correct: that Christ descended to Limbo and saved the worthy pre-Christians. Virgil responds:

... "Io era nuovo in questo stato,

quando ci vidi venire un possente, con segno di vittoria coronato.

Trasseci l'ombra del primo parente, d'Abèl suo figlio e quella di Noè, di Moisè legista e ubidente;

Abraàm patriarca e Davìd re, Israèl con lo padre e co' suoi nati e con Rachele, per cui tanto fé,

e altri molti, e feceli beati.

E vo' che sappi che, dinanzi ad essi, spiriti umani non eran salvati."

(Inf. 4.52-63)

Indeed it is true, declares Virgil who witnessed the event, that "un possente" descended into Hell. Any soul-resident wishing to describe, 1266 years later almost to the hour, Dante's own descent, might provide a comparable account to Virgil's even though Dante is not really a "possente." the formula "vo' che sappi" and shifts the pilgrim's attention from the souls who left, to a time before "un possente" descended to this place. Virgil "wants" Dante "to know" that such an event had never happened before. Virgil, with his partial knowledge of things Christian, has perceived the importance of this "possente" not only for those who ascended with Him, but also for those like Virgil who witnessed Christ's descent, yet were left in Limbo. Virgil had arrived in Limbo just in time to bear witness to this once-ever liberation of select pre-Christians. But Christ's descent means something more to Virgil than simply a unique event he witnessed. He is one who is left behind, who is not taken out of Limbo in the company of Abel, Noah and all the others. On this occasion when pre-Christians were judged, when half of the Celestial Rose would be instantly filled by this horde now freed from Limbo, Virgil was also judged. And it is a negative judgement or else Virgil would not have remained just a witness, just a bystander looking in on the action, his status as an outsider confirmed eternally.

Generally Virgil's role as guide is distinct from his role as soul-resident. In Limbo, instead, the two roles are blurred. Virgil is both Dante's guide and a soul in Limbo who was there 1266 years before to witness the crucial event of the descensus Christi of which until now Dante pilgrim had only abstract knowledge. 
When Virgil and Dante leave Limbo and move on to the second circle Virgil is once again just guide, almost as if Virgil the soul-resident had been left behind like Marcia, Homer, Ovid, Lucan and the others.

The third and last repetition of the formula "vo' che sappi" occurs as Virgil and Dante proceed towards the seventh circle. Here Virgil is in full control of the situation despite the menacing Minotaur who guards this circle of the violent. The repetition of the formula begs the comparison between Virgil's guiding competence at the approach to the 7 th circle and his performance as guide in Limbo, the context of the first two occurrences of the formula. In this place, unlike in Limbo, Virgil need not identify with the punished and the condemned, nor need he be defensive about those who surround him. After Virgil succeeds in verbally bludgeoning the Minotaur on the ruined slope, the two poets descend:

Così prendemmo via giù per lo scarco

di quelle pietre, che spesso moviensi

sotto i miei piedi per lo novo carco.

Io gia pensando; e quei disse: "Tu pensi

forse a questa ruina, ch'è guardata

da quell'ira bestial ch'i' ora spensi."

(Inf. 12.28-33)

With the third and last repetition of the formula below, Virgil recalls the other time he left Limbo just after his death and he further recalls as he did in Inferno 4 that very important event, the descensus Christi:

“Or vo' che sappi che l'altra fiata ch'i' discesi qua giù nel basso inferno, questa roccia non era ancor cascata.

Ma certo poco pria, se ben discerno, che venisse colui che la gran preda levò a Dite del cerchio superno,

da tutte parti l'alta valle feda tremò sì, ch'i' pensai che l'universo sentisse amor, per lo qual è chi creda

più volte il mondo in caòsso converso; $\mathrm{e}$ in quel punto questa vecchia roccia, qui e altrove, tal fece riverso."

Just as the poet subtly makes the link between Inferno 4 and Inferno 12. by repeating "vo" che sappi," Virgil overtly links the canti by repeating his description of what he experienced when Christ descended to Hell. He remembers here in Inferno 12 what he thought in the "alta valle" (Limbo), when "un possente" crowned with the sign of victory had made blessed ("feceli beati") some Old Testament figures and "altri molti," something he already described to Dante in 
Inferno 4. Now, he is confirming what the formula has already disclosed to us: there is a relationship between the earthquake that was described up there ("l'alta valle") in Inferno 4 and the result of it described here in Inferno 12, namely "la ruina." $"$

If one compares Virgil's account of Christ's descent after the second repetition of the formula back in the "alta valle" in Inferno 4 with the third repetition of the formula in Inferno 12, his description is now less detailed. Here, for example, there is no list of the actual names of some of the great biblical figures. One presumes that the description need not be detailed because it has all been said before. But if it has all been said before, why does Virgil repeat at all his account of the descensus Christi? Because here Virgil adds something important he did not describe in Inferno 4, although he had prepared the reader for it there on line 15:

\footnotetext{
"Or discendiam qua giù nel cieco mondo," cominciò il poeta tutto smorto.

"Io sarò primo, e tu sarai secondo."
}

The line, "io sarò primo, e tu sarai secondo," describes the relation guide/pilgrim and at the same time anticipates the reference to Virgil's own descent that he will clearly make in Inferno 12, immediately following the third and last repetition of the formula "vo' che sappi." He was the "first" outsider to venture into the depths of this "cieco mondo," shortly before Christ's descent into Limbo, and now Dante is the "second."

Virgil's prior descent is first described in Inferno 9, and just before that he refers to the descensus Christi. ${ }^{11}$ At the end of Inferno 8 when Virgil's negotiations with the devils before the city of Dis seem to have broken down, while his "ciglia avea rase / d'ogne baldanza" (8.118-19), he nonetheless assures his charge that he shall win in the end and adds:

"Questa lor tracotanza non è nova; ché già l'usaro a men segreta porta, la qual sanza serrame ancor si trova.

Sovr'essa vedestù la scritta morta."

(Inf. 8.124-27)

With this allusion to the descensus Christi the reader remembers Inferno 4 and the detailed description by Virgil of this event. Preceding that description was the allusion to Virgil's pallor, his "color" (Inf. 4.16) which had caused Dante to fear the folly of his barely commenced journey. Reference to Virgil's "color" reappears on the first line of Inferno 9, just four lines after the above quote: 
veggendo il duca mio tornare in volta,

più tosto dentro il suo novo ristrinse.

As in Inferno 4 the pilgrim is now very fearful and for the same reason: the pallor in Virgil's face suggests that he may not be up to the task of guiding. Thus a few lines later the nervous pilgrim asks his guide for, and obtains, reassurance:

"In questo fondo de la trista conca discende mai alcun del primo grado, che sol per pena ha la speranza cionca?"

Questa question fec'io; e quei "Di rado incontra," mi rispuose, "che di noi faccia il cammino alcun per qual io vado.

Ver è ch'altra fiata qua giù fui, congiurato da quella Eritón cruda che richiamava l'ombre a' corpi sui.

Di poco era di me la carne nuda, ch'ella mi fece intrar dentr'a quel muro, per trarne un spirto del cerchio di Giuda.

Quell'è 'l più basso loco e 'l più oscuro, e 'l più lontan dal ciel che tutto gira: ben so 'l cammin; però ti fa sicuro."

As Christ, God incarnate, just after he lost his flesh made his way down into Limbo past those who would have tried to block his way, so too does Dante, incarnate, led by Virgil, make his way down by God's will. And Virgil soon after he lost his flesh ("Di poco era di me la carne nuda" 9.25), like Christ, descended. Although Virgil descended much further down than Christ, inside the city of Dis to Giudecca, the reason for the descent is similar. Christ descended to Limbo to take ("trasseci" Inf. 4.55) the worthy pre-Christians so that they might be saved from Hell, and Virgil descended to take ("per trame" Inf. 9.27) "un spirto" and save it from deepest Hell.

Virgil descended "l'altra fiata" as the "primo" into deepest Hell and now accompanies Dante, the "secondo," once more into deepest Hell. ${ }^{12}$ Again in Inferno 12 Virgil refers to his prior journey by repeating "l'altra fiata," just after the formula, "vo' che sappi."

Dante's use of the verb "discendere" when describing the three journeys or descents into Hell, that of Virgil first, then Christ, then Virgil and Dante together (all linked by the linguistic code) also constitutes a link. Preceding the first occurrence of the formula "vo' che sappi" in Inferno 4, just before Virgil and Dante reach Limbo, Virgil declares: "Or discendiam qua giù nel cieco mondo" (4.13). The use of the verb "discendere" plus the "cieco mondo," has particular significance when one juxtaposes the journey now of Virgil and Dante with the 
one of Christ then. I repeat the question Dante asks Virgil in Inferno 9 which allows Virgil to tell of his prior journey down into deepest Hell:

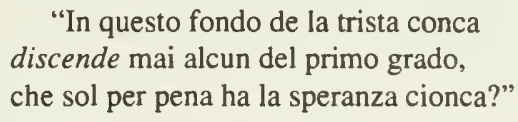

(Inf. 9.16-18)

This question, with "discende," coming as it does just after the allusion to the descensus Christi at the end of Inferno 8, suggests that the reader connect Virgil's descent with Christ's. And finally Virgil's second reference to his prior descent, again in close textual proximity to the reference to the descensus Christi, is preceded by the third and last occurrence of the formula:

"Or vo' che sappi che l'altra fiata

ch'i' discesi qua giù nel basso inferno, questa roccia non era ancor cascata."

(Inf. 12.34-36)

Virgil descended before Christ, by journeying from Limbo to the very bottom of Hell. Essentially Virgil descended so that one individual, Dante, can descend and then ascend, just as Christ descended and ascended to show the way for all humankind to descend and then ascend towards salvation: "descendit ad inferos . . . ascendit ad caelos" (Apostles' Creed). The formula "vo' che sappi" in Inferno 12 focuses on Virgil who descended to the 9th circle and then ascended back to Limbo. Virgil's descent is important for the pilgrim and also for the reader: Virgil having been the "primo" to descend, will know the way to show Dante, the "secondo," some 1300 years later, when he will be sent down again to guide Dante and make his journey possible, with all that that journey will determine, namely the writing of the book. ${ }^{13}$

The three repetitions of "vo' che sappi" plus the two repetitions of "color," when viewed together, constitute a linguistic code which leads the reader to examine the significance of the parallelism between Virgil's descent and the descent of Christ and of Dante into Hell. Virgil, not saved by Christ, descended and ascended so that one soul might be saved the pain of the ninth circle ("per trarne un spirto del cerchio di Giuda" Inf. 9.27). Christ descended and took ("trasseci l'ombra del primo parente ..." Inf. 4.55) a host of souls so they might be saved the pain of Hell. The linguistic code, then, highlights that the extraordinary descents of Virgil, of Christ, and now of Dante have one significant aspect in common: all of them have to do with saving souls. It is precisely this highlighting of the commonality of purpose of three descents which provides us with an insight that anticipates the culminating moment of Dante's meeting with Cacciaguida in Paradise: the Christian readers of Dante's book who will have descended and ascended with Virgil, with Christ, with Dante pilgrim, may also 
be counted among those who will be saved the pain of Hell and will fill some of the few remaining places in the Celestial Rose.

\section{University of Victoria}

\section{NOTES}

1 All quotations of the Commedia are taken from Dante Alighieri, La Commedia secondo l'antica vulgata.

2 For a study of linguistic formulas and their function in medieval texts see Ruth House Webber.

3 The concordance used in this study is Lovera, Concordanza.

4 For a comprehensive discussion of the descensus Christi and annotated bibliography see Iannucci, "La 'discesa"”.

5 Emphasis in all quotes is mine.

6 There is no theological foundation for adults being left behind in Limbo after the descensus Christi. See Iannucci, "Limbo," for a study of Dante's departure from theological thought and how that departure impacts on his Limbo, Virgil, and the Commedia as a whole.

7 "Or" precedes the first and third repetition of the formula "vo' che sappi" but not the second.

8 See Inf. 21.114 , for the reference to the time of Dante's journey being some 1266 years later than Christ's descent.

9 It is primarily in Inferno 12 and later in Inferno 21 that the joumeying pilgrim and the reader see the actual result of the earthquake which took place 1266 years before and which happened just before Christ's descent into Limbo. In Inferno 21 when Virgil and Dante flee from the devils of the 5th Round they will discover that all the bridges are down which had connected it with the 6th Round. This is something Virgil would not have known since he journeyed this way before the earthquake, before Christ's descent to Limbo. There is also the barest mention of damage done to Hell due to the earthquake in Inf. 5.34, with mention of the "ruina."

10 The "or" plus the formula has two functions. Appearing as it does in the first and the third instance of the formula it frames the route of these three signposts. As well these are the two instances when Virgil refers to himself in the text that immediately follows them. In the first instance as soul-resident of Limbo and in the last as one who already journeyed through Hell.

11 For analysis of the descensus Christi within the context of this episode see Iannucci, "Dottrina."

12 The formula "altra fiata," with the denotation of one other time is unique to Inf. 9.22 and Inf. 12.34. Furthermore they both refer to the same event: Virgil's prior journey to the bottom of Hell. "L'una e l'altra fiata" (Inf. 10.50) and "una e altra fiata" (Inf. 30.3) are the only other two references in the Commedia which contain "altra fiata" however with the "una" preceding the "altra fiata" they denote more than one time.

13 No doubt a reason why Beatrice journeyed down to Limbo and requested that Virgil aid Dante, was because she was aware Virgil knew the way, having embarked on that journey before. Virgil's first joumey was therefore part of the Providential plan.

\section{WORKS CITED}

Alighieri, Dante. La Commedia secondo l'antica vulgata. Ed. Giorgio Petrocchi. 4 vols. Milano: Mondadori, 1966-67. 
Iannucci, Amilcare A. "La 'discesa di Beatrice agli Inferi'." Forma ed evento nella Divina Commedia. Roma: Bulzoni, 1984. 51-84.

. "Dottrina e allegoria in Inferno VIII, 67 - IX, 105." Dante e le forme dell' allegoresi. Ed. Michelangelo Picone. Ravenna: Longo, 1987. 99-124.

. "Limbo: The Emptiness of Time." Studi danteschi 52 (1979-80): 69-128.

Lovera, Luciano. Concordanza della Commedia di Dante Alighieri. Torino: Einaudi, 1975.

Webber, Ruth House. "The Diction of the Roncesvalles Fragment." Homenaje a Rodriguez Moñino. Vol. 2. Madrid: Castalia, 1966. 311-21 